\title{
How small communities respond to environmental change: patterns from tropical to polar ecosystems
}

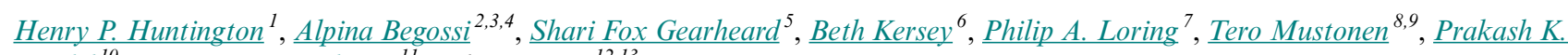 \\ $\underline{\text { Paudel }}^{10}$, Renato A. M. Silvano ${ }^{11}$ and $\underline{\text { Ron Vave }}^{12,13}$
}

\begin{abstract}
Local communities throughout the world are experiencing extensive social, cultural, economic, environmental, and climatic changes. Rather than passively accepting the effects of such changes, many communities are responding in various ways to take advantage of opportunities and to minimize negative impacts. We review examples from 13 cases around the world to identify patterns in how communities have been able to respond to change. Communities are able to respond by making changes in the time and location of activities, by using different species, by developing or using new technologies, and by organizing themselves internally or in networks. The possible responses a community can make on its own constitute the autonomous response space. When communities work with others to respond, they are in the collaborative response space. These findings suggest that assessments concerning climate and other forms of change should include local responses as a foundation for policy recommendations, recognizing that both autonomous and collaborative responses can contribute to adaptation. Policies designed to achieve adaptation or sustainability should consider ways to expand the autonomous response space, thus freeing local initiative, while also making the collaborative response space more cooperative, thus providing support to communities rather than imposing limitations.
\end{abstract}

Key Words: climate change; environmental change; management; policy; response space; social-ecological systems

\section{INTRODUCTION}

Local communities throughout the world are experiencing social, cultural, economic, environmental, and climatic changes at rates and to an extent greater than previously experienced (ACIA 2005, AMSA 2009, McClanahan and Cinner 2011, Nakashima et al. 2012, CAFF 2013, IPCC 2014). Much attention has been given to documenting those changes, their impacts, and the presumed vulnerability, resilience, and adaptability of the communities in question (e.g., Adger et al. 2003, AHDR 2004, 2014, Ford and Smit 2004, Ford et al. 2014, 2015, Shackleton et al. 2015, Garfin and Parris 2016). Further studies have considered the day-to-day context in which these changes are experienced, including the actions that individuals and communities are already taking in response to changes (e.g., Hovelsrud and Smit 2010, Ifejika Speranza et al. 2010, Halder et al. 2012, Loring et al. 2016). These actions largely fall in the category of experience-based responses identified by Amaru and Chhetri (2013). Adaptation entails a continuous process of learning about best use of available resources and capacity (Fazey et al. 2007, Lebel et al. 2006). Thus, a key factor for the continued existence of humans is their adaptive capability in light of environmental change (Winterhalder 1980, Smit and Wandel 2006). Here, learning is a key means of adaptation and resilience (Kelly and Adger 2000, McGray et al. 2007, Tschakert and Dietrich 2010, Amaru and Chhetri 2013). A rich literature explores social-ecological systems (e.g., Bodin and Tengö 2012, McGinnis and Ostrom 2014) and the role of institutions (e.g., Ostrom 2005, 2007) to understand the impacts of and responses to change, including how new institutions come to develop through these adaptation actions.
In this context, community responses to change have been categorized, for example by Thornton and Manasfi (2010) who identify mechanisms of adaptation, which can also be considered as the directions in which communities can adjust, or what they can do. The characteristics that support effective responses have also been categorized, for example by Walker and Salt (2012) who identify strategies for resilience, which can also be considered as the ability of communities to adjust, or why they can do it. The ways in which these mechanisms are influenced by local social, economic, cultural, and environmental contexts are important factors to consider (Geels 2011), in addition to the details of the responses themselves.

Building on these analyses of what communities can do and why they are able do it, we consider here how communities are able to respond to change, the details of which result from the combination of the nature of the change itself with the abilities, resources, and capital that communities have at their disposal. Research on how communities innovate, for example within the area of socio-technological innovation and cultural evolution, generally suggest that people and communities respond to new conditions within an innovation space or niche (Geels 2011, Waring et al. 2015). This literature draws attention to the structural forces exogenous to local communities that shape the innovation space. We focus on the equally important question of how people create new options or paths for themselves and their communities within, and perhaps despite, these structural constraints (e.g., Garud and Karnøe 2001).

To begin to explore this question of how people respond to change, we consider a selection of cases from around the world

${ }^{1}$ Huntington Consulting, ${ }^{2}$ Capesca/Nepa/Unicamp, Rua Albert Einsteins/n, Campinas, SP, ${ }^{3}$ Fisheries and Food Institute, ${ }^{4}$ Ecomar/Unisanta/Santos, SP, ${ }^{5}$ Cooperative Institute for Research in Environmental Sciences, National Snow and Ice Data Center, University of Colorado Boulder, ${ }^{6}$ Iowa State University, ${ }^{7}$ School of Environment and Sustainability, University of Saskatchewan, ${ }^{8}$ University of Eastern Finland, ${ }^{9}$ Snowchange Cooperative, ${ }^{10}$ Center for Conservation Biology, Kathmandu Institute of Applied Sciences, Kathmandu, Nepal, ${ }^{11}$ Department of Ecology, Federal University of Rio Grande do Sul (UFRGS), ${ }^{12}$ Institute of Applied Science, University of the South Pacific, Fiji, ${ }^{13}$ Marine Biology Graduate Program, University of Hawai'i at Mānoa 
(Fig. 1) in which indigenous or artisanal communities have responded to change. Each case is familiar to one or more of the authors, all of whom work with small hunting, fishing, and farming communities. The social cohesion and localized resource use patterns of these communities make them suitable examples for an initial analysis. Our assumption is that community responses reflect local perceptions and local knowledge of what is possible and desirable.

Fig. 1. Map of case study locations.

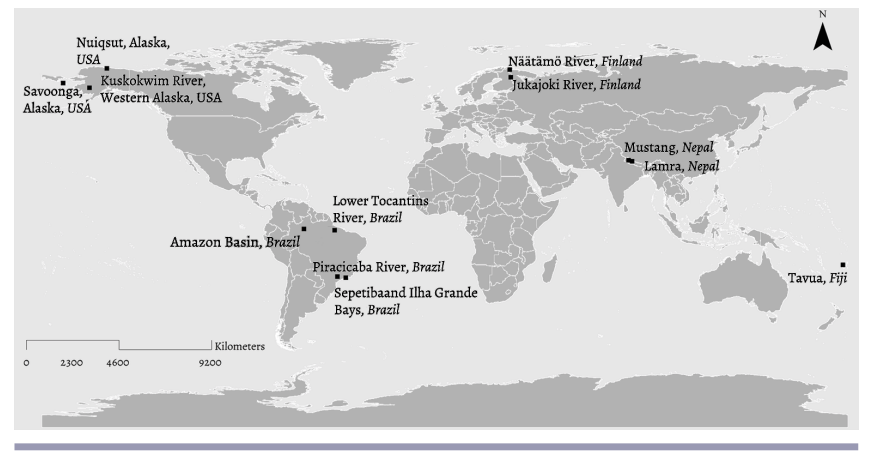

Given that most people respond to change in a way that prefers maintaining the status quo (Thornton and Manasfi 2010), innovation toward adaptation or transformation requires flexibility, both the possibility of and willingness to change what one does (e.g., Irvine and Kaplan 2001, Thornton and Manasfi 2010). We suggest thinking of these possibilities as the response space in which one can alter one's patterns of activity (Tompkins and Adger 2005). We neither claim that future changes will necessarily be met in these communities with effective responses, nor do we imply that a community's ability to respond effectively somehow negates the environmental injustices of climate change or other drivers of change (e.g., Loring 2013, Oliver-Smith 2013). We expect that a better understanding of how communities are able to respond to change will provide insights into policies and practices that can better support community response in a broad range of environmental and cultural contexts. Our paper is a first step in that direction.

\section{METHODS}

To explore the question of how communities respond to change, we chose 13 examples from the experiences of the authors that provide a set of critical cases for our analysis and synthesis (Patton 2015). Following Yin (2009), we sought "revelatory" cases, ones that illustrate a particular phenomenon, e.g., response to change, allowing us to test and develop our ideas concerning community response through "confirmatory" cases. Assembling and analyzing cases where communities failed to respond would be a different exercise, beyond the intent of our work, though perhaps instructive in its own way. The examples are not intended to be representative, but are geographically, culturally, economically, ecologically, and politically diverse, and are sufficient in number to reduce selection bias from the influence of any individual author. We believe our examples provide an adequate basis for exploring the "how" of community response to change in hunting, farming, and fishing communities in freshwater, coastal, and forest ecosystems from the Arctic to the tropics.
We analyzed each case study based on our own experience and published sources where available, to determine (a) the major change(s) that had occurred, (b) the community's response(s), (c) the initiator(s) of the response, (d) the result(s) of the response (s), and (e) what was required from the community or others to make the response(s) possible. We considered the context in which communities were able to act, selecting the community capitals framework of Emery and Flora (2006) and its identification of seven distinct types of capital, which we further distinguished into assets and constraints on the ability of each community to act. We compared the type of response with Thornton and Manasfi's (2010) typology of mechanisms (the what) and with Walker and Salt's (2012) typology of strategies (the why), to confirm that our examples are indeed diverse in both senses, with at least one example matching each element of both typologies. Finally, we put the case studies in an order that illustrates the explanationbuilding approach described by Yin (2009), in which each case adds additional insight to our understanding of how communities respond to change. From the analysis of the case studies, we created a synthesis of results by identifying common elements and patterns in the search for a better understanding of how communities are able to respond to change in diverse contexts.

\section{RESULTS: ANALYSIS}

Table 1 provides an overview of each case study, (a) noting the type of ecosystem in which the community is located, (b) outlining the five elements noted in Methods above, and (c) providing the major sources of information for each case study. The order of the case studies follows the presentation of results below. The cases cover a wide range of ecosystems and resources used; include hunting, fishing, and agriculture; describe four drivers (climate change, species introduction, overexploitation, and anthropogenic disturbance); and reveal a range of results and conditions that enable the achievement of those results. The range and variety of experiences allowed us to build and test ideas that are likely to be more robust than if they had come solely from case studies that were too similar to one another.

Table 2 summarizes the capitals, expressed as assets and constraints, of each community as it responded to change. Note that some characteristics can be assets in one form of capital and constraints in another. For example, geographical remoteness tends to reduce political capital, which is a constraint to response, but it can also allow for greater spatial mobility without impinging on other communities' use areas, which is an asset. Remoteness can also mean less attention from regulators, allowing for greater local flexibility. Not surprisingly, small communities tend to be high in social, cultural, and certain human and natural assets, but also limited by political and economic constraints, including infrastructure. These patterns undoubtedly shape the types of responses that are possible for these communities, but still allow the set of cases to exhibit all of the mechanisms and strategies listed in Table 3.

Table 3 categorizes the responses in each case by mechanisms (per Thornton and Manasfi 2010) and by strategy (per Walker and Salt 2012). The examples cover a diversity of mechanisms and strategies, illustrating the ability of the communities in the case studies to make use of one or more of the options available to them. There is no guarantee, of course, that a community attempting to respond to a change would have any options 
Table 1. Summary characteristics of the case studies used in this paper.

\begin{tabular}{|c|c|c|c|c|c|c|}
\hline $\begin{array}{l}\text { Community/Region; } \\
\text { Ecosystem }\end{array}$ & Change(s) & Response(s) & $\begin{array}{l}\text { Initiator(s) of } \\
\text { response(s) }\end{array}$ & Result(s) & $\begin{array}{l}\text { What was needed to } \\
\text { achieve that result }\end{array}$ & Key Source(s) \\
\hline $\begin{array}{l}\text { Savoonga, Alaska } \\
\text { (whaling); } \\
\text { Arctic marine }\end{array}$ & $\begin{array}{l}\text { Worse spring weather, } \\
\text { later fall freeze-up of } \\
\text { sea ice }\end{array}$ & $\begin{array}{l}\text { Started hunt for } \\
\text { bowhead whales } \\
\text { (Balaena mysticetus) in } \\
\text { fall as well as spring }\end{array}$ & $\begin{array}{l}\text { Whaling } \\
\text { captains }\end{array}$ & $\begin{array}{l}40 \% \text { of whales now } \\
\text { taken in fall, closer to } \\
\text { village and requiring } \\
\text { less gasoline }\end{array}$ & $\begin{array}{l}\text { Having an open hunting } \\
\text { season }\end{array}$ & Noongwook et al. 2007 \\
\hline $\begin{array}{l}\text { Savoonga, Alaska } \\
\text { (crabbing); } \\
\text { Arctic marine }\end{array}$ & $\begin{array}{l}\text { Brown spiny king crab } \\
\text { (hanasaki crab, } \\
\text { Paralithodes brevipes) } \\
\text { reaching the northern } \\
\text { Bering Sea }\end{array}$ & $\begin{array}{l}\text { Harvesting of the newly } \\
\text { available species }\end{array}$ & Individuals & $\begin{array}{l}\text { New food source } \\
\text { New harvesting activity }\end{array}$ & $\begin{array}{l}\text { Lack of regulatory } \\
\text { obstacles }\end{array}$ & $\begin{array}{l}\text { H.P.H., summer } 2013 \text {, } \\
\text { personal observation }\end{array}$ \\
\hline $\begin{array}{l}\text { Piracicaba River, Brazil; } \\
\text { Tropical freshwater }\end{array}$ & $\begin{array}{l}\text { Large dam and } \\
\text { reservoir downstream } \\
\text { Presence of non- } \\
\text { native fish species }\end{array}$ & $\begin{array}{l}\text { Fishing directed to fish } \\
\text { species resilient to dams } \\
\text { Fishing of non-native } \\
\text { fishes }\end{array}$ & Fishers & $\begin{array}{l}\text { Continued commercial } \\
\text { fishing } \\
\text { Marketing of non- } \\
\text { native species }\end{array}$ & $\begin{array}{l}\text { No restrictions on } \\
\text { gillnets } \\
\text { Fishers' local ecological } \\
\text { knowledge, including } \\
\text { about non-native } \\
\text { species }\end{array}$ & $\begin{array}{l}\text { Silvano and Begossi } \\
1998,2001,2002\end{array}$ \\
\hline $\begin{array}{l}\text { Kuskokwim River/ } \\
\text { Western Alaska; } \\
\text { Subarctic freshwater }\end{array}$ & $\begin{array}{l}\text { Crash of Pacific } \\
\text { salmon (Oncorhyncus } \\
\text { spp.) returns to river }\end{array}$ & $\begin{array}{l}\text { Harvesting other } \\
\text { species } \\
\text { Extending sharing } \\
\text { networks } \\
\text { Better long-term } \\
\text { storage of salmon when } \\
\text { available }\end{array}$ & Women & $\begin{array}{l}\text { Ability to continue to } \\
\text { provide food for family, } \\
\text { within a traditional } \\
\text { lifestyle }\end{array}$ & $\begin{array}{l}\text { Communication with } \\
\text { others within and } \\
\text { outside the region } \\
\text { Ability to innovate } \\
\text { Access to elders }\end{array}$ & Kersey 2011 \\
\hline $\begin{array}{l}\text { Näätämö River, Finland; } \\
\text { Subarctic freshwater }\end{array}$ & $\begin{array}{l}\text { Climate change } \\
\text { impacts to the } \\
\text { Atlantic salmon } \\
\text { (Salmo salar), past } \\
\text { state actions } \\
\text { (dredging) }\end{array}$ & $\begin{array}{l}\text { Collaborative plan for } \\
\text { the whole catchment } \\
\text { area, making Sámi land } \\
\text { use visible }\end{array}$ & $\begin{array}{l}\text { Community } \\
\text { leaders, Skolt } \\
\text { Sámi female and } \\
\text { male fishermen }\end{array}$ & $\begin{array}{l}\text { Identification of sites } \\
\text { damaged, harvest of } \\
\text { predator fish, land use } \\
\text { maps, restored } \\
\text { spawning sites }\end{array}$ & $\begin{array}{l}\text { UN funding } \\
\text { Leadership by Sámi } \\
\text { women }\end{array}$ & $\begin{array}{l}\text { Mustonen and } \\
\text { Mustonen 2011, } \\
\text { Mustonen 2012, CAFF } \\
\text { 2013, Mustonen and } \\
\text { Fedoroff } 2013\end{array}$ \\
\hline $\begin{array}{l}\text { Mustang, Nepal; } \\
\text { Alpine terrestrial }\end{array}$ & $\begin{array}{l}\text { Climate-related } \\
\text { decline in apple } \\
\text { production at lower } \\
\text { altitudes }\end{array}$ & $\begin{array}{l}\text { Converted apple } \\
\text { orchards into cereal } \\
\text { fields } \\
\text { Moved apple orchards } \\
\text { to higher elevation }\end{array}$ & Farmers & $\begin{array}{l}\text { More labor and less } \\
\text { profit } \\
\text { New food sources }\end{array}$ & $\begin{array}{l}\text { Adaption of new } \\
\text { technology }\end{array}$ & $\begin{array}{l}\text { Manandhar et al. 2011, } \\
2014\end{array}$ \\
\hline $\begin{array}{l}\text { Lamra, Jumla, Nepal; } \\
\text { Temperate terrestrial }\end{array}$ & $\begin{array}{l}\text { Erratic and low } \\
\text { precipitation }\end{array}$ & $\begin{array}{l}\text { Replaced rice paddies } \\
\text { with millet fields }\end{array}$ & Farmers & $\begin{array}{l}\text { New food source } \\
\text { Continued food } \\
\text { production }\end{array}$ & Supporting institutions & $\begin{array}{l}\text { Gentle and Maraseni } \\
2012\end{array}$ \\
\hline $\begin{array}{l}\text { Nuiqsut, Alaska; } \\
\text { Arctic marine }\end{array}$ & $\begin{array}{l}\text { Worse fall weather } \\
\text { Less time available } \\
\text { away from jobs, etc. }\end{array}$ & $\begin{array}{l}\text { Shorter fall whaling } \\
\text { season } \\
\text { Take food with them } \\
\text { instead of hunting for } \\
\text { food during whaling } \\
\text { season }\end{array}$ & $\begin{array}{l}\text { Whaling } \\
\text { captains }\end{array}$ & $\begin{array}{l}\text { Hunting now done in } \\
2-3 \text { weeks } \\
\text { Whaling is efficient, } \\
\text { effective } \\
\text { Loss of social time } \\
\text { during whaling season }\end{array}$ & Larger boats/engines & Galginaitis 2013 \\
\hline $\begin{array}{l}\text { Lower Tocantins River, } \\
\text { Brazil; } \\
\text { Tropical freshwater }\end{array}$ & $\begin{array}{l}\text { Large dam built } \\
\text { upstream }\end{array}$ & $\begin{array}{l}\text { Fishing directed to fish } \\
\text { species resilient to dams }\end{array}$ & Fishers & $\begin{array}{l}\text { Continued commercial } \\
\text { fishing }\end{array}$ & $\begin{array}{l}\text { No restrictions on } \\
\text { gillnets } \\
\text { Fishers' local ecological } \\
\text { knowledge } \\
\text { Distance from } \\
\text { competitors }\end{array}$ & $\begin{array}{l}\text { Silvano et al. } 2009 \\
\text { Hallwass et al. } 2013 a, b\end{array}$ \\
\hline $\begin{array}{l}\text { Jukajoki River, Finland; } \\
\text { Subarctic freshwater }\end{array}$ & $\begin{array}{l}\text { Fish death, loss of } \\
\text { birds from } \\
\text { acidification caused } \\
\text { by the Finnish Power } \\
\text { Company (VAPO) }\end{array}$ & $\begin{array}{l}\text { Community-led } \\
\text { restoration plan for the } \\
\text { whole catchment area }\end{array}$ & $\begin{array}{l}\text { Community } \\
\text { leaders, } \\
\text { subsistence } \\
\text { fishermen }\end{array}$ & $\begin{array}{l}\text { Designation of } \\
\text { protected wetland } \\
\text { A model for heavily- } \\
\text { damaged catchment } \\
\text { areas in boreal } \\
\text { Best practices } \\
\text { recognized by the UN }\end{array}$ & $\begin{array}{l}\text { Belief in Finnish } \\
\text { traditional knowledge } \\
\text { and its capacity to } \\
\text { monitor, and, in some } \\
\text { cases, challenge state } \\
\text { discourses }\end{array}$ & $\begin{array}{l}\text { Mustonen 2013, 2014b, } \\
\text { UNDP } 2014\end{array}$ \\
\hline $\begin{array}{l}\text { Sepetiba and Ilha Grande } \\
\text { Bays, Brazil; } \\
\text { Tropical marine }\end{array}$ & $\begin{array}{l}\text { Pollution (heavy } \\
\text { metals and domestic } \\
\text { discharges) }\end{array}$ & $\begin{array}{l}\text { Organization by fishers } \\
\text { to address local } \\
\text { demands } \\
\text { Oyster cultivation }\end{array}$ & $\begin{array}{l}\text { Leaders of } \\
\text { fishers } \\
\text { associations }\end{array}$ & $\begin{array}{l}\text { Changes in company } \\
\text { practices } \\
\text { New skills for fishers }\end{array}$ & $\begin{array}{l}\text { Social cohesion among } \\
\text { fishers }\end{array}$ & $\begin{array}{l}\text { Begossi et al. 2010, } \\
2011,2012\end{array}$ \\
\hline $\begin{array}{l}\text { Amazon Basin, Brazil; } \\
\text { Tropical freshwater }\end{array}$ & $\begin{array}{l}\text { Invasion of lakes by } \\
\text { commercial fisheries } \\
\text { Increased fishing } \\
\text { pressure }\end{array}$ & $\begin{array}{l}\text { Communication and } \\
\text { organization among } \\
\text { small-scale fishers } \\
\text { Agreements about } \\
\text { fishing access } \\
\text { Fishers established } \\
\text { comanagement and } \\
\text { rules }\end{array}$ & $\begin{array}{l}\text { Leaders of local } \\
\text { fishers }\end{array}$ & $\begin{array}{l}\text { Recognition of } \\
\text { territorial rights } \\
\text { Increased fish harvests } \\
\text { Managed lakes }\end{array}$ & $\begin{array}{l}\text { Communication } \\
\text { networks }\end{array}$ & $\begin{array}{l}\text { McGrath et al. } 1993 \text {, } \\
\text { 2008, Almeida et al. } \\
\text { 2009, Begossi 2010, } \\
\text { Lopes et al. 2011, } \\
\text { Silvano et al. } 2014\end{array}$ \\
\hline $\begin{array}{l}\text { Tavua, Fiji; } \\
\text { Tropical marine }\end{array}$ & $\begin{array}{l}\text { Increased fishing } \\
\text { pressure }\end{array}$ & $\begin{array}{l}\text { Authorizing } \\
\text { commercial fishers to } \\
\text { be fish wardens } \\
\text { Including commercial } \\
\text { fishers in what is } \\
\text { normally a closed } \\
\text { indigenous } \\
\text { management system }\end{array}$ & $\begin{array}{l}\text { Chief, tribal, and } \\
\text { clan elders }\end{array}$ & $\begin{array}{l}\text { Better observance of } \\
\text { fishing rules, including } \\
\text { taboo area } \\
\text { Better communication } \\
\text { between fishers and } \\
\text { community leaders }\end{array}$ & $\begin{array}{l}\text { Willingness of the chief } \\
\text { of Tavua to innovate } \\
\text { Respected traditional } \\
\text { governance structure } \\
\text { and leader }\end{array}$ & $\begin{array}{l}\text { UNDP 2012, Nasiko } \\
\text { 2013; R.V., May 2012, } \\
\text { personal observation }\end{array}$ \\
\hline
\end{tabular}


Table 2. Forms of community capital (per Emery and Flora 2006) and their expression as assets or (constraints) in each case study locale.

\begin{tabular}{|c|c|c|c|c|c|c|c|}
\hline Location & Human & Social & Cultural & Political & Financial & Built & Natural \\
\hline Example & $\begin{array}{l}\text { Individual skills, } \\
\text { abilities }\end{array}$ & $\begin{array}{l}\text { Cohesion, } \\
\text { leadership }\end{array}$ & $\begin{array}{l}\text { Flexibility, } \\
\text { restrictions }\end{array}$ & Access to power & Access to money & Infrastructure & Climate, resources \\
\hline $\begin{array}{l}\text { Savoonga, } \\
\text { Alaska } \\
\text { (whaling) }\end{array}$ & $\begin{array}{l}\text { Highly } \\
\text { experienced } \\
\text { whaling captains, } \\
\text { deep traditional } \\
\text { knowledge }\end{array}$ & $\begin{array}{l}\text { Whaling } \\
\text { Captains } \\
\text { Association, } \\
\text { structure of } \\
\text { whaling crews }\end{array}$ & $\begin{array}{l}\text { Flexibility, } \\
\text { innovation are } \\
\text { valued }\end{array}$ & $\begin{array}{l}\text { Alaska Eskimo } \\
\text { Whaling } \\
\text { Commission } \\
\text { (Remote } \\
\text { community) }\end{array}$ & $\begin{array}{l}\text { (High poverty } \\
\text { rate) } \\
\text { (High cost of } \\
\text { goods) }\end{array}$ & Already have boats & $\begin{array}{l}\text { In whales' } \\
\text { migratory path }\end{array}$ \\
\hline $\begin{array}{l}\text { Savoonga, } \\
\text { Alaska } \\
\text { (crabbing) }\end{array}$ & $\begin{array}{l}\text { Deep knowledge } \\
\text { of coastline, } \\
\text { resources }\end{array}$ & $\begin{array}{l}\text { Cohesive and } \\
\text { extended } \\
\text { families, strong } \\
\text { cooperation }\end{array}$ & $\begin{array}{l}\text { Flexibility, } \\
\text { innovation are } \\
\text { valued }\end{array}$ & $\begin{array}{l}\text { (Remote } \\
\text { community) }\end{array}$ & $\begin{array}{l}\text { (High poverty } \\
\text { rate) } \\
\text { (High cost of } \\
\text { goods) }\end{array}$ & Already have boats & $\begin{array}{l}\text { Arrival of new, } \\
\text { harvestable species }\end{array}$ \\
\hline $\begin{array}{l}\text { Piracicaba River, } \\
\text { Brazil }\end{array}$ & $\begin{array}{l}\text { Skilled fishers } \\
\text { with good local } \\
\text { knowledge }\end{array}$ & $\begin{array}{l}\text { (No strong } \\
\text { leaders, fishers } \\
\text { act mostly } \\
\text { individually) }\end{array}$ & $\begin{array}{l}\text { (Individual } \\
\text { flexibility) }\end{array}$ & $\begin{array}{l}\text { (Communities are } \\
\text { small and usually } \\
\text { ignored by the } \\
\text { government) }\end{array}$ & (Relative poverty) & $\begin{array}{l}\text { Most own } \\
\text { motorized small } \\
\text { boats, fishing gear, } \\
\text { freezers to store } \\
\text { fish; Communities } \\
\text { have electricity, } \\
\text { roads }\end{array}$ & $\begin{array}{l}\text { (Impacts from a } \\
\text { dam and reservoir, } \\
\text { pollution, } \\
\text { deforestation) }\end{array}$ \\
\hline $\begin{array}{l}\text { Kuskokwim } \\
\text { River/Western } \\
\text { Alaska }\end{array}$ & $\begin{array}{l}\text { Deep knowledge } \\
\text { of cultural } \\
\text { resources }\end{array}$ & $\begin{array}{l}\text { Cohesive } \\
\text { families, sharing } \\
\text { networks }\end{array}$ & $\begin{array}{l}\text { Flexibility, } \\
\text { innovation are } \\
\text { valued }\end{array}$ & $\begin{array}{l}\text { (Remote } \\
\text { communities) }\end{array}$ & $\begin{array}{l}\text { (High poverty } \\
\text { rate) } \\
\text { (High cost of } \\
\text { goods) }\end{array}$ & $\begin{array}{l}\text { Already have } \\
\text { fishing equipment }\end{array}$ & $\begin{array}{l}\text { Diversity of fish to } \\
\text { harvest, ways to } \\
\text { process fish }\end{array}$ \\
\hline $\begin{array}{l}\text { Näätämö River, } \\
\text { Finland }\end{array}$ & $\begin{array}{l}\text { Indigenous Sámi } \\
\text { knowledge, } \\
\text { experienced } \\
\text { fishermen }\end{array}$ & $\begin{array}{l}\text { Women in } \\
\text { leadership }\end{array}$ & $\begin{array}{l}\text { Strong traditional } \\
\text { culture among } \\
\text { Skolt Sámi, } \\
\text { adaptability }\end{array}$ & $\begin{array}{l}\text { (Marginalized, very } \\
\text { remote community) }\end{array}$ & $\begin{array}{l}\text { (High poverty } \\
\text { rate) }\end{array}$ & $\begin{array}{l}\text { (No road within } \\
12 \mathrm{~km} \text { ) }\end{array}$ & $\begin{array}{l}\text { (Loss and } \\
\text { degradation of } \\
\text { habitat, presence } \\
\text { of predatory } \\
\text { fishes) }\end{array}$ \\
\hline Mustang, Nepal & $\begin{array}{l}\text { Deep knowledge } \\
\text { of cropping } \\
\text { system }\end{array}$ & $\begin{array}{l}\text { Established } \\
\text { social structure, } \\
\text { cohesive families }\end{array}$ & $\begin{array}{l}\text { Flexibility, } \\
\text { innovations are } \\
\text { valued }\end{array}$ & $\begin{array}{l}\text { (Remote } \\
\text { communities) }\end{array}$ & $\begin{array}{l}\text { (High poverty } \\
\text { rate) }\end{array}$ & Established fields & $\begin{array}{l}\text { Diversity of } \\
\text { cropping system } \\
\text { due to altitudinal } \\
\text { gradient }\end{array}$ \\
\hline $\begin{array}{l}\text { Lamra, Jumla, } \\
\text { Nepal }\end{array}$ & $\begin{array}{l}\text { Local knowledge } \\
\text { and traditional } \\
\text { practices }\end{array}$ & $\begin{array}{l}\text { Established } \\
\text { social structure, } \\
\text { cohesive families }\end{array}$ & $\begin{array}{l}\text { Flexibility, } \\
\text { innovations are } \\
\text { valued }\end{array}$ & $\begin{array}{l}\text { (Remote } \\
\text { communities) }\end{array}$ & $\begin{array}{l}\text { Access to loans } \\
\text { (High poverty } \\
\text { rate) }\end{array}$ & $\begin{array}{l}\text { Established fields } \\
\text { Irrigation }\end{array}$ & $\begin{array}{l}\text { Diverse cropping } \\
\text { patterns to adopt }\end{array}$ \\
\hline Nuiqsut & $\begin{array}{l}\text { Highly } \\
\text { experienced } \\
\text { whaling captains }\end{array}$ & $\begin{array}{l}\text { Whaling } \\
\text { Captains } \\
\text { Association, } \\
\text { structure of } \\
\text { whaling crews }\end{array}$ & $\begin{array}{l}\text { Flexibility, } \\
\text { innovation are } \\
\text { valued }\end{array}$ & $\begin{array}{l}\text { Alaska Eskimo } \\
\text { Whaling } \\
\text { Commission } \\
\text { (Remote } \\
\text { community) }\end{array}$ & $\begin{array}{l}\text { Oil revenue } \\
\text { (High poverty } \\
\text { rate) } \\
\text { (High cost of } \\
\text { goods) }\end{array}$ & $\begin{array}{l}\text { Already have boats } \\
\text { (Offshore oil } \\
\text { developments) }\end{array}$ & $\begin{array}{l}\text { In whales' } \\
\text { migratory path }\end{array}$ \\
\hline $\begin{array}{l}\text { Lower Tocantins } \\
\text { River, Brazil }\end{array}$ & $\begin{array}{l}\text { Experienced } \\
\text { fishers with } \\
\text { developed local } \\
\text { knowledge }\end{array}$ & $\begin{array}{l}\text { Some } \\
\text { communities } \\
\text { have strong } \\
\text { leadership }\end{array}$ & $\begin{array}{l}\text { Innovation can be } \\
\text { adopted by } \\
\text { individuals }\end{array}$ & $\begin{array}{l}\text { (Local communities } \\
\text { are usually } \\
\text { disregarded by the } \\
\text { federal government) }\end{array}$ & $\begin{array}{l}\text { (High poverty } \\
\text { rate) }\end{array}$ & $\begin{array}{l}\text { Most own dugout } \\
\text { canoes and fishing } \\
\text { gear (Lack of } \\
\text { electricity, etc.) }\end{array}$ & $\begin{array}{l}\text { High fish diversity } \\
\text { (Impacts from } \\
\text { dams) }\end{array}$ \\
\hline $\begin{array}{l}\text { Jukajoki River, } \\
\text { Finland }\end{array}$ & $\begin{array}{l}\text { Fishermen with } \\
\text { traditional } \\
\text { knowledge }\end{array}$ & $\begin{array}{l}\text { Existence of } \\
\text { village council, } \\
\text { fishers' } \\
\text { organization }\end{array}$ & $\begin{array}{l}\text { Cohesiveness, } \\
\text { ability to self- } \\
\text { organize }\end{array}$ & $\begin{array}{l}\text { (Resource } \\
\text { periphery, no access } \\
\text { to power/decisions) }\end{array}$ & $\begin{array}{l}\text { (Marginalized, no } \\
\text { financial assets) }\end{array}$ & $\begin{array}{l}\text { Roads, forestry, } \\
\text { boats }\end{array}$ & $\begin{array}{l}\text { Ability of } \\
\text { ecosystem to } \\
\text { restore its health } \\
\text { (Two major } \\
\text { pollution events } \\
\text { that killed fish) }\end{array}$ \\
\hline $\begin{array}{l}\text { Sepetiba and } \\
\text { Ilha Grande } \\
\text { Bays, Brazil }\end{array}$ & $\begin{array}{l}\text { Skills for } \\
\text { confronting } \\
\text { polluters }\end{array}$ & $\begin{array}{l}\text { Cohesion among } \\
\text { fishers, existence } \\
\text { of fishers } \\
\text { association }\end{array}$ & $\begin{array}{l}\text { Innovation is } \\
\text { valued }\end{array}$ & $\begin{array}{l}\text { Companies may } \\
\text { listen to fishers } \\
\text { (Government } \\
\text { agencies do not) }\end{array}$ & (Relative poverty) & $\begin{array}{l}\text { Most own small- } \\
\text { scale boats, such } \\
\text { as motor canoes or } \\
\text { medium size boats } \\
\text { (Restrictions on } \\
\text { relocating waste } \\
\text { discharge } \\
\text { facilities) }\end{array}$ & $\begin{array}{l}\text { High diversity of } \\
\text { fish (about } 35 \\
\text { species at Sepetiba } \\
\text { Bay) }\end{array}$ \\
\hline $\begin{array}{l}\text { Amazon Basin, } \\
\text { Brazil }\end{array}$ & $\begin{array}{l}\text { History of } \\
\text { grassroots } \\
\text { activism, e.g., } \\
\text { from Liberation } \\
\text { Theology } \\
\text { movement }\end{array}$ & $\begin{array}{l}\text { Strong cohesion, } \\
\text { compared with } \\
\text { other small-scale } \\
\text { fisheries of } \\
\text { Brazil }\end{array}$ & $\begin{array}{l}\text { Flexible systems } \\
\text { where many } \\
\text { innovative } \\
\text { processes occur }\end{array}$ & $\begin{array}{l}\text { (Government } \\
\text { interference with } \\
\text { local initiatives) }\end{array}$ & $\begin{array}{l}\text { (High poverty } \\
\text { rate) }\end{array}$ & $\begin{array}{l}\text { Most own dugout } \\
\text { canoes and fishing } \\
\text { gear, existing } \\
\text { cooperative } \\
\text { networks } \\
\text { (Lack of } \\
\text { electricity, etc.) }\end{array}$ & High fish diversity \\
\hline Tavua, Fiji & $\begin{array}{l}\text { Fishermen with } \\
\text { traditional } \\
\text { knowledge }\end{array}$ & $\begin{array}{l}\text { Strong } \\
\text { leadership } \\
\text { structure }\end{array}$ & $\begin{array}{l}\text { Respect for } \\
\text { traditions, elders; } \\
\text { ability of chief to } \\
\text { innovate }\end{array}$ & $\begin{array}{l}\text { (Lack of access to } \\
\text { government } \\
\text { support for } \\
\text { enforcement) }\end{array}$ & (Relative poverty) & $\begin{array}{l}\text { Many own boats, } \\
\text { fishing gear }\end{array}$ & $\begin{array}{l}\text { Local protected } \\
\text { area }\end{array}$ \\
\hline
\end{tabular}


available, and no community is obliged to use all of the options available. Nonetheless, the use of a variety of mechanisms and strategies suggests that keeping options open is a useful goal, rather than expecting that any single mechanism or strategy will be available and appropriate when needed.

Table 3. Mechanisms and strategies of response in the case studies.

\begin{tabular}{|c|c|c|}
\hline Community/Region & $\begin{array}{l}\text { Mechanism(s) of } \\
\text { response, following } \\
\text { Thornton and } \\
\text { Manasfi (2010) }\end{array}$ & $\begin{array}{c}\text { Strategy/ies of response, } \\
\text { following Walker and } \\
\text { Salt (2012) }\end{array}$ \\
\hline $\begin{array}{l}\text { Savoonga, Alaska: } \\
\text { whaling }\end{array}$ & $\begin{array}{l}\text { Mobility } \\
\text { Innovation }\end{array}$ & Openness \\
\hline $\begin{array}{l}\text { Savoonga, Alaska: } \\
\text { crabbing }\end{array}$ & Diversification & $\begin{array}{l}\text { Diversity } \\
\text { Openness }\end{array}$ \\
\hline Piracicaba River, & Exchange & Diversity \\
\hline Brazil & Innovation & Feedback Loops \\
\hline $\begin{array}{l}\text { Kuskokwim River/ } \\
\text { Western Alaska }\end{array}$ & $\begin{array}{l}\text { Exchange } \\
\text { Innovation } \\
\text { Revitalization }\end{array}$ & $\begin{array}{c}\text { Feedback Loops Social/ } \\
\text { Human Capital }\end{array}$ \\
\hline Näätämö River, & Exchange & Feedback Loops \\
\hline Finland & Revitalization & Social/Human Capital \\
\hline Mustang, Nepal & Mobility & Openness \\
\hline Lamra, Jumla, Nepal & Exchange & $\begin{array}{c}\text { Reserves } \\
\text { Social/Human Capital }\end{array}$ \\
\hline Nuiqsut, Alaska & Innovation & Reserves \\
\hline Lower Tocantins & Mobility & Diversity \\
\hline River, Brazil & $\begin{array}{l}\text { Exchange } \\
\text { Pooling } \\
\text { Innovation }\end{array}$ & Feedback Loops \\
\hline $\begin{array}{l}\text { Jukajoki River, } \\
\text { Finland }\end{array}$ & $\begin{array}{c}\text { Exchange } \\
\text { Innovation } \\
\text { Revitalization }\end{array}$ & $\begin{array}{c}\text { Reserves } \\
\text { Social/Human Capital }\end{array}$ \\
\hline Sepetiba and Ilha & Exchange & Diversity \\
\hline Grande Bays, Brazil & $\begin{array}{l}\text { Pooling } \\
\text { Innovation }\end{array}$ & Social/Human Capital \\
\hline Amazon Basin, Brazil & $\begin{array}{l}\text { Mobility } \\
\text { Pooling } \\
\text { Innovation }\end{array}$ & $\begin{array}{c}\text { Diversity } \\
\text { Social/Human Capital }\end{array}$ \\
\hline Tavua, Fiji & $\begin{array}{l}\text { Exchange } \\
\text { Pooling } \\
\text { Innovation }\end{array}$ & $\begin{array}{c}\text { Openness } \\
\text { Feedback Loops } \\
\text { Social/Human Capital }\end{array}$ \\
\hline
\end{tabular}

Building on the information in the summary tables, we provide a brief description of each case study and how it adds to our understanding of how communities respond to change (the main references for each case are provided in Table 1). We begin with cases in which broad-scale and local environmental changes have produced new opportunities, which lead to perhaps the simplest responses. Then we look at cases where environmental changes have reduced opportunities (sometimes in combination with human pressures), forcing communities to make a change. The last examples concern increases in competition from other users, again forcing a response as opportunities diminish.

\section{Savoonga, Alaska: a new season for whaling}

Although climate change is often cited as a cause or expected cause of loss of resources and access thereto for hunting and fishing communities (e.g., Ford and Smit 2004), in some cases it can also provide new opportunities. With regard to fall whaling at least, Savoonga experienced a beneficial change that it was able to use to advantage, developing a new bowhead whaling (Balaena mysticetus) season to supplement low harvests due to poor weather and ice conditions during spring whaling or with walrus (Odobenus rosmarus) hunting (e.g., Huntington et al. 2013). Flexibility and innovation were critical, exercised through the existing structure of whaling crews, and were unconstrained by regulatory limits such as a fixed whaling season.

Savoonga, Alaska: a new species to harvest

Savoonga has experienced another new opportunity due to climate change (warming of ocean waters). The arrival of the hanasaki or brown spiny king crab (Paralithodes brevipes) in the northern Bering Sea has resulted in a new and enthusiastic crab fishery by the St. Lawrence Island Yupik. Families are able to go crabbing together, allowing young people to join in the production of food for local use. The ecosystem consequences of the arrival of the hanasaki crab are as yet unknown, but the absence of restrictions has allowed the Yupik to take advantage of their arrival. Again, the community was able to make use of a new opportunity.

Piracicaba River, southeastern Brazil: exploiting invasive species by acquiring knowledge

Anthropogenic environmental impacts are well known on local and regional scales. The construction of the Tietê River dam affected existing fishes, but also led to the arrival of two new fish species, the intentionally introduced corvina (Plagioscion squamosissimus) and the naturally invasive armoured catfish cascudo (Liposarcus aff. anisitsi). As was the case for Savoonga and the brown spiny king crab, fishers along the Piracicaba River have dealt with these changes by directing fishing efforts to catch and sell these introduced fishes, drawing on detailed knowledge they have developed since the fishes' arrival. This suggests that such local ecological knowledge may be rapidly acquired and may contribute to adaptations to change.

Kuskokwim River, Alaska: women's strategies for sustaining food security

Along the Kuskokwim River, on the other hand, environmental and perhaps human influences led to the failure of the salmon run in 2000, a seasonal cycle that the Yup'ik villages in the watershed have relied on for centuries. Women in the thousands of affected households (Yates 2000) adapted by drawing on social networks and traditional knowledge to resume older methods and develop new ones for extending the use of the salmon that were available and for using other fishes as substitutes. Here, a negative impact from environmental change forced the responses taken by the women of the region.

\section{Näätämö River, Finland: adapting to climate change through} collaborative management and salmon habitat restoration Climate change, combined with local habitat degradation, has greatly reduced the abundance of Atlantic salmon in the Näätämö River. Starting in 2011, the Skolt Sámi initiated the very first collaborative management plan for the river, drawing on the longpreserved Sámi cosmologies and traditional mindset. As with the Kuskokwim, environmental loss has been met with selforganization and a renewed emphasis on traditional knowledge. The first modern land use and occupancy map of Sámi activities has been produced, Sámi knowledge has contributed to the observation of new insect species in the catchment area (Mustonen and Feodoroff 2013), damaged sites have been chosen 
for restoration, and a sustained harvest of predator fish such as northern pike (Esox lucius) and burbot (Lota lota) has been initiated.

\section{Mustang, Nepal: shifting crop types and locations}

Farmers in the lower Mustang region enjoyed good apple production starting in the early 1960s. In recent years, climate change has caused apple production to plummet sharply in lower areas but has also allowed it to expand into higher altitudes. As in the Kuskokwim case, a negative impact from environmental change forced the response, which was made easier by the relatively sparse population (3.8 individuals per square $\mathrm{km}$; GON 2012). The availability of space into which farmers could expand may have facilitated people in moving to higher altitudes while retaining lower areas for cereal cultivation.

\section{Lamra, Jumla, Nepal: shifting cropping systems}

Climate change also forced changes in crop production systems in the area of the Lamra village development committee (VDC) of Jumla District. Famous for its rice production at unusually high altitudes (up to $3000 \mathrm{~m}$; Uhlig 1978), a rise in average temperature and low and erratic precipitation in recent years have caused a drastic decline in production. To support the switch from paddy cropping systems to millet-based cropping systems, farmers and their supporting institutions, e.g., a saving and credit group, an irrigation group, have evolved proactively to respond.

\section{Nuiqsut, Alaska: a shorter whaling season}

The whalers of Nuiqsut faced both environmental and social change in recent decades, which combined to reduce the time available for fall bowhead whaling. Thanks to the tax and business revenue from nearby oilfields, Nuiqsut is unusual in our case studies for having financial assets that supported the purchase of larger boats with more powerful and reliable engines. As with Savoonga's fall whaling, the existing structure of whaling crews allowed whaling captains to initiate the response, so that Nuiqsut whalers could continue to obtain the whales they need despite new constraints on the time available for the hunt.

\section{Lower Tocantins River, Amazon Basin, Brazil: shifting target species}

Large dams, deforestation, and increased fishing pressure (Ribeiro et al. 1995, Petrere 1996) have had negative impacts on fishes and fisheries along the Tocantins River. In addition to redirecting fishing effort and changing gear types, the region's fishers have participated in comanagement efforts, building social and political capital to create more effective management methods that in turn have increased fish abundance and improved fishing yields. As in the Kuskokwim, environmental change has led to greater use of social assets.

\section{Jukajoki, Selkie, Finland: communal restoration of watershed following fish death}

Discharges of highly acidic pollution ( $\mathrm{pH}$ 2.77) from the Finnish Power Company (VAPO) peat production site killed all the fish in the river Jukajoki in June 2010 and again in June 2011. As with the Tocantins, these impacts were observed by fishers along the river, who organized to initiate a watershed-wide restoration effort, drawing on oral histories and local knowledge. A lawsuit forced VAPO to end its operations and won protected status for the Linnunsuo wetland unit, which has since become the top-most habitat for wading birds in Finland, and is home to rarities such as the Northern Pintail (Anas acuta) and Terek Sandpiper (Xenus cinereus).

\section{Sepetiba and Ilha Grande Bays, Brazil: organizing to protect fisheries}

Pollution combined with competition for space (from tourism) and resources (from industrial fishing) reduced customary smallscale fisheries in Sepetiba Bay, with about 15 fishing communities, and Ilha Grande Bay, with about 34 fishing communities (Begossi 1992, Cynara et al. 2006, Lacerda and Molisane 2006, Begossi and Lopes 2014). Fishers in Sepetiba developed new activities and self-organized to negotiate with polluters and legislators, resulting in continued livelihoods there. The fishers of Ilha Grande Bay, on the other hand, have done little to learn new skills or organize themselves, and the future of fishing there is unclear (Trimble and Johnson 2013).

Amazon Basin, Brazil: networks of artisanal fishers

Direct competition for fish stocks is another form of local anthropogenic impact. Faced with the arrival of large-scale commercial fishers, small-scale fishers in the Amazon Basin used networks that had been built from the 1960s onward to help fishers organize their response, including the creation of fishing agreements (de Castro and McGrath 2003, McGrath et al. 2007). As with other cases of local environmental degradation, selforganization was a key element of the response. Although there is relatively little monitoring of the outcomes of these agreements, interviews with local fishers indicate that fishers in communities that established fishing agreements have higher fishing yields.

Tavua, Fiji: inclusive fisheries management

The district of Tavua also experienced increased competition, including poaching, leading to a long-term decline in reef fish catch within the local fishing ground. A productive portion of the reef measuring $13 \mathrm{~km}^{2}$ has been protected by the people of Tavua since 2003, but increased poaching and fishing pressure continued. Here, too, self-organization and innovation lay at the heart of the response. In 2012, the late chief of Tavua, Ratu Jale Kuwe Ratu, convened a workshop that led to two major, innovative changes. First, commercial fishermen could also be trained and authorized as fish wardens. Second, a Tavua Fishermen's Council was created, from which a representative would be invited to attend the normally closed meetings of the Bose Vanua, the Tavua tribal and clan elders. The Council was further empowered to make decisions and be responsible for issuance of fishing licenses.

\section{RESULTS: SYNTHESIS}

In the synthesis, we start with the results of the analysis above and consider similarities and patterns in how communities are able to respond within their response space. In some cases, such as Savoonga and the Piracicaba, the community simply took advantage of new opportunities. In these cases, there were no constraints limiting their ability to make use of new species or new times for hunting. In the rest of the cases, where changes altered or reduced opportunities, most communities responded by some form of self-organization, using or creating fishers' associations, comanagement arrangements, savings and loan and irrigation groups, and so on. It should not be surprising that changes reducing opportunities (negative impacts) require more effort and reorganization than changes that provide new 
opportunities, but this finding illustrates the capacity for communities to develop, when necessary, new modes of interaction with one another, with others, and with the natural world.

For some matters, communities are on their own with little to constrain them except the limits of the natural world. Although such a situation provides little support beyond the community's own intellectual, social, and financial resources, it may also mean that the community can move, innovate, and otherwise change their practices without interference from the outside. Thus, Savoonga was able to start whaling in fall and catching the brown spiny king crab when it appeared in their waters. Nuiqsut was able to adjust their approach to whaling. The people of the Kuskokwim River were able to revitalize old ways and improve sharing of ideas and food. The farmers of Mustang were able to move their orchards uphill. The Brazilian fishers were able to shift target species and methods. The people of Tavua were able to restructure their decision-making system. There was no requirement that any of these changes be made, and no restraint on doing so.

In other matters, communities require some degree of interaction with others outside the community. These cases often, but not always, stemmed from changes caused by local factors, either local anthropogenic environmental impacts or increased competition from other users. The farmers of Lamra benefited from the resources of the saving and credit group and the irrigation group, which provided capital and expertise. The Brazilian fishers benefited from the ability to create comanagement regimes under Brazilian law and from their negotiations with others who were influencing the waters in which they fish. In Jukajoki, interaction outside the community included conflict through the legal system, where local residents were victorious. In Näätämö, the Sámi were able to access funding from the United Nations to support their efforts. Although some response may have been possible in these cases without involving others, the effectiveness of those responses would likely have been lower. Undoubtedly there are also cases where outside influence curtails potential responses. As one example, whalers in Alaska cannot switch to other species because the International Whaling Commission prohibits it (IWC 2015).

This dichotomy, between actions the community can take on its own and those that require interaction with others, suggests that the response space can be divided into two parts. The part of the response space that is within control of the community can be considered the autonomous response space. The part of the response space that requires the involvement of others outside the community can be considered the collaborative response space, though depending on circumstances the involvement of others may be restrictive rather than collaborative. We next take up the implications of this observation.

\section{DISCUSSION}

We have considered the 13 case studies for what they can tell us about response to change, specifically how communities are able to respond to change. Our analysis identified a variety of responses and types of responses, comprising the response space available to a community. Our synthesis distinguished the autonomous from the collaborative response space, characterized by the presence or absence of outside influence and help. (This is in partial contrast to the use of "autonomous response" to refer to private action as opposed to public action, or "planned response," by Monnereau and Abraham 2013, among others.) Here we consider the implications of this finding, referring to institutions, social-ecological systems, the boundaries of the possible, and the potential difference between short-term response and long-term adaptation.

The role of institutions is important. Ostrom (2007:23) defines institutions as "shared concepts used by humans in repetitive situations." Ostrom (2010) further asserts that efforts at multiple, if not overlapping, smaller scales, e.g., families, communities, states, etc., promote more beneficial responses to change than do global efforts. These smaller, polycentric efforts are better positioned to experiment and explore novelty in developing more localized and better fitting responses, by incorporating local knowledge, norms, and values. There is value in larger scaled, global efforts, for example, in securing needed investment, but at the local level, participants in these different polycentric systems can observe and learn from each other, through trial and error. The consideration of the case studies is important precisely because they offer an opportunity to learn from experience.

It is worth noting that the case studies describe innovative responses rather than repetitive situations, and thus fall into Ostrom's (2005) "action arena," which is shaped by the biophysical and socioeconomic context, including existing institutional arrangements. Thus, the existence of communication networks (Kuskokwim River, Amazon Basin), savings and loan and irrigation groups (Lamra), the Bose Vanua (Tavua), and other institutions provided a basis for innovation in that the communities were able to use these institutions in novel ways. In other cases, communities had to create new organizations, such as the fishers' associations in Näätämö, Jukajoki, and Sepetiba Bay. If they persist, these new associations will become institutions as they address repetitive situations, as anticipated by Ostrom (2007).

Many of the cases presented in this paper display endogenous response capability, the inherent, self-defined capacity to address problems at hand. This endogenous power is very different from official governance; in fact, most of these cases operate on the peripheries of official power and governance. Sometimes the actions and adaptation measures can be in opposition to or in conflict with top-down decision-making processes, e.g., conflicts in Brazil between large- and small-scale fishers, between tourism and small-scale fishers, between industrial pollution and smallscale fishers. As several of our examples show, local communities can produce and reproduce their own interpretations of scale and temporality (Mustonen 2014a). Even in the collaborative response space, it is essential to remain aware of the specific details of community contexts and the potential imbalances in power between small communities and larger institutions such as governments.

In both the autonomous and collaborative response spaces, networks can help spread ideas and express the need for support. These networks can be developed at different scales, such as kin, villages, communities, and NGOs, among others, are likely to influence the type, strength, and effectiveness of responses. The fishers from Sepetiba Bay built up strong associations, enhancing what they were able to achieve in the collaborative response space. 
Networks and associations were also important in the Amazon, in the case of the fishing agreements. The freshwater fisheries of Piracicaba and Tocantins rivers directed responses by shifting target species and fish technologies and sharing that information among practitioners. Diversification is another outcome, as seen in the increase in tourism in the Atlantic Forest coast. Ilha Grande Bay is another example of diversifying activities as response (Lopes et al. 2015). The increased use of sharing networks by women along the Kuskokwim River similarly helped communities respond by creating a wider base for providing food and by pooling and revitalizing traditional knowledge.

Social-ecological system (SES) frameworks provide another way of examining the factors that shape community response to change. In this approach, scales in time and space are important considerations (e.g., Cumming et al. 2006, Perry et al. 2011), the examination of which could add further insight into the relationship between autonomous and collaborative response spaces and the factors that determine the size and characteristics of each. Furthermore, the degree to which self-organization was involved in the responses of the case studies suggests that the dynamics of the social system in particular may be especially important, as was found in a detailed examination of the Bering Sea SES (Haynie and Huntington 2016).

There are, of course, external factors beyond the control of the community or its collaborators. Apple trees can only grow so high in the mountains of Mustang. Fish populations can only support a finite level of fishing. These factors create the outer boundaries of the possible. Recognizing these limits is essential, but it is also important to recognize the power of innovation to create previously unseen possibilities, such as targeting an invasive species or taking up mariculture. Acquiring new ecological knowledge to exploit invasive species, as observed in the Piracicaba River or in Savoonga, is one such innovation that can greatly assist in finding new possibilities, though innovation can also lead to overharvest and other problems as well. At the same time, invasive species are a major threat to biodiversity worldwide (Mack et al. 2000) and either biologists or local people may have difficulty reducing the abundance of nonexploited exotic species (Shine and Doody 2011). In this sense, the adaptive response of exploiting exotic or invasive species may address two problems at once: control of invaders and provision of food and income to local communities (e.g., Dierking and Campora 2009).

Furthermore, short-term responses are not always long-term solutions. An important future research area is the exploration of how these short-term responses to change do or do not translate into long-term adaptive strategies. For example, fishers in the Tocantins River use gillnets with relatively small mesh sizes (Hallwass et al. 2013b, Silvano et al. 2017). Although this strategy may be an effective short-term response to a decrease in the abundance of large fish, it also may compromise fish stocks in the long term (e.g., Welcomme et al. 2010).

\section{SPECULATION}

As our examination of the "how" of community response is a first step, we now enter into a speculative realm about what our findings may mean and where further research is needed, particularly with regard to policies that can affect the size of and access to response spaces. Neither the autonomous nor the collaborative response space, nor the boundary between them, is fixed. Changing conditions may increase or decrease what is possible, i.e., the size and configuration of the overall response space. New regulations may shift a potential response from autonomous to collaborative, whereas devolution of authority can work in the opposite direction. Furthermore, autonomous responses are not necessarily preferable to collaborative ones. Collaboration brings the potential for support as well as conflict, and autonomous responses may not take advantage of new ideas or resources. Hovelsrud and Smit (2010), for example, present examples of a wide variety of current responses to change from around the Arctic, noting an emphasis on traditional knowledge as well as a recognition of the role of regional and national institutions. Nonetheless, a strong community role is likely to be essential to making sure that responses to change reflect local conditions and preferences in addition to innovations and resources that may come from elsewhere.

Awareness of the distinction between autonomous and collaborative responses allows communities and their potential collaborators - governments, companies, nongovernmental organizations (NGOs), other communities, academia - to better understand their respective roles and how outcomes may be improved by carefully combining local knowledge and customs with outside expertise and resources. The optimal balance will vary from case to case and will be affected by the potential for user conflicts, the allocation of limited resources, and other factors.

The study of local responses points also to various policy implications. Maintaining and enhancing community flexibility to create a large autonomous response space provides an opportunity for communities to respond on their own terms, in ways that correspond to local practices, beliefs, traditions, and priorities. Many such responses are difficult to predict and thus to plan for. The development of fall whaling in Savoonga, for example, was not planned for in the allocation of the whaling quota among Alaska villages, nor in any discussions about seasons. A large autonomous response space creates room for a range of innovation, rather than constraining creativity into only a few areas (Loring et al. 2011).

Similarly, if the collaborative response space is cooperative rather than confrontational, responses will be facilitated rather than inhibited (Harrison and Loring 2014). In Lamra, for example, local farmers are changing their cropping systems, aided by advice from experts about high-yield varieties and appropriate methods for cultivating those varieties. This cooperative approach helps expand the response space by giving the farmers more options. Such options, however, differ between and within communities. Poor communities, for example, have limited knowledge, poor assets, and inadequate external support and therefore may fall behind in using such responses as compared with better-off communities (Gentle and Maraseni 2012). Tracking the effects of those responses can provide important feedback about what works and what does not, guiding further actions and identifying responses that are truly adaptive. A crucial question is what determines true adaptive response. It is widely accepted that innovations should promote optimum use of local resources with minimum external support, and the system should be manageable at community levels (Bell and Morse 2003). This is particularly important for collaborative response space. Cultivation of a different type of apple, for example, can be an alternative to range 
shift of apple cultivation in Mustang. But this could be too costly if the new variety is vulnerable to disease and pests, requiring further outside assistance if not dependency rather than fostering local capacity.

Some challenges must be addressed to allow the development of policies that properly consider the responses of local communities. Expanding the autonomous response space and making the collaborative response space cooperative both require a transfer of some leadership and power from central governments and large institutions to individuals and local communities (e.g., Amaru and Chhetri 2013). Some governments are reluctant either to consider the knowledge and practices of local peoples or to allow them to participate in decisions related to natural resources management. Similarly, some outside experts remain skeptical about local practices and local knowledge, and undervalue or ignore them (e.g., Huntington 2011). In addition, the responses of one community may conflict not only with government regulations but also with other communities. For example, an expansion in the area of fishing or crop cultivation may collide with resource use areas of other communities, or increased tourism may benefit some individuals or communities while bringing impacts that disturb others. In open-access or common-property systems such as seas and waters (Acheson 2015), clashes between users may undermine the effectiveness of responses, though agreements such as those established among fishermen in the Amazon Basin could be a promising arrangement.

\section{CONCLUSION}

Responses are not simply a product of change nor of an abstract accounting of community capacity or elements of resilience. More focus in research on the actions of local communities in response to climate change expands our understanding of locallevel planning, governance, and values for the future. Previous studies illustrate the need for climate change response strategies that better accommodate existing local institutions, local knowledge and experience, and local leadership (e.g., Hovelsrud et al. 2010, Amaru and Chhetri 2013, Kehew et al. 2013). At the same time, although adaptation to climate and other changes is often viewed in terms of local action, it is important to recognize that a number of interacting influences, e.g. institutions, policies, regulations, or knowledge, from international to regional levels may shape which adaptations can take place locally (Keskitalo 2009, Nilsson et al. 2012). There are important intersections between trajectories of capacity, institutions, technologies, culture, and behavior, at multiple levels, that form the context for action in response to climate change and other environmental and societal changes (Burch 2011, Burch et al. 2014).

We show here that communities from a broad range of ecosystems and geographical regions, in land, sea, and freshwaters, have developed dynamic responses to change. The synthesis of all these cases can help identify ways in which communities can deal with complex global problems and changes at local or regional scales. Although these responses have been driven by distinct factors according to local context, distant and unrelated communities have developed similar responses and patterns in how they respond to change. Further research can examine patterns among these and more case studies in greater detail, to advance our understanding of the characteristics that shape responses (e.g.,
Ostrom 2009). Our results suggest that policy makers and resource managers could achieve better long-term adaptive solutions from an effective combination of autonomous and collaborative responses.

Responses to this article can be read online at: http://www.ecologyandsociety.org/issues/responses. $\mathrm{php} / 9171$

\begin{abstract}
Acknowledgments:
We are grateful to all our community research partners, who have generously shared their insights and experiences with us in many locations at many times. We thank the U.S. National Science Foundation for its support through the Sustainable Futures North project (Award No. 1262722), for H.P.H., S.G., and P.A.L. The research on which the Brazilian examples are based was funded by FAPESP grants 09/11154-3, the CNPq productivity scholarship to A.B. and R. A.M.S, Eletronortel ANEEL contract 4500057477. T. $M$.'s research and contribution to this paper has been made possible by the Turvetuotanto ja vesistövaikutusten hallinta: Relevanteista faktoista tehokkaisiin normeihin/Water Management and Peat Project: From the Relevant Facts to Effective Norms (WAPEAT) (Suomen Akatemian hanke 263465) Project. We thank the editor and two anonymous reviewers who provided detailed and constructive comments that greatly improved an earlier version of this paper.
\end{abstract}

\section{LITERATURE CITED}

Acheson, J. M. 2015. Private land and common oceans: analysis of the development of property regimes. Current Anthropology 56(1):28-55. http://dx.doi.org/10.1086/679482

Adger, W. N., S. Huq, K. Brown, D. Conway, and M. Hulme. 2003. Adaptation to climate change in the developing world. Progress in Development Studies 3:179-195. http://dx.doi. org/10.1191/1464993403ps060oa

Almeida, O. T., K. Lorenzen, and D. G. McGrath. 2009. Fishing agreements in the lower Amazon: for gain and restraint. Fisheries Management and Ecology 16:61-67. http://dx.doi.org/10.1111/ j.1365-2400.2008.00647.x

Amaru, S., and N. B. Chhetri. 2013. Climate adaptation: institutional response to environmental constraints, and the need for increased flexibility, participation, and integration of approaches. Applied Geography 39:128-139. http://dx.doi. org/10.1016/j.apgeog.2012.12.006

Arctic Climate Impact Assessment (ACIA). 2005. Arctic climate impact assessment. Cambridge University Press, Cambridge, UK.

Arctic Human Development Report (AHDR). 2004. Arctic human development report. Stefansson Arctic Institute, Akureyri, Iceland.

Arctic Human Development Report (AHDR). 2014. Arctic human development report: regional processes and global linkages. Nordic Council of Ministers, Copenhagen, Denmark. 
Arctic Marine Shipping Assessment (AMSA). 2009. Arctic marine shipping assessment. Arctic Council, Tromsø, Norway.

Begossi, A. 1992. The use of optimal foraging theory in the understanding of fishing strategies: a case from Sepetiba Bay (Rio de Janeiro, Brazil). Human Ecology 20:463-475. http://dx.doi. org/10.1007/BF00890430

Begossi, A. 2010. Small-scale fisheries in Latin America: management models and challenges. Maritime Studies 9:5-12.

Begossi, A., and P. F. M. Lopes, editors. 2014. Paraty small-scale fisheries. Editora Rima, São Carlos, Brazil.

Begossi, A., P. F. M. Lopes, L. Oliveira, and H. Nakano. 2010. Ecologia de pescadore sartesanais da Baia de Ilha Grande. Ed. Rima, São Carlos, Brazil.

Begossi, A., P. H. May, P. F. Lopes, L. E. C. Oliveira, V. da Vinha, and R. A. M. Silvano. 2011. Compensation for environmental services from artisanal fisheries in SE Brazil: policy and technical strategies. Ecological Economics 71:25-32. http://dx.doi. org/10.1016/j.ecolecon.2011.09.008

Begossi, A., S. V. Salivonchyk, V. Nora, P. F. Lopes, and R. A. M. Silvano. 2012. The paraty artisanal fishery (southeastern Brazilian coast): ethnoecology and management of a socialecological system (SES). Journal of Ethnobiology and Ethnomedicine 8:22. http://dx.doi.org/10.1186/1746-4269-8-22

Bell, S., and S. Morse. 2003. Measuring sustainability: learning from doing. Earthscan, London, UK.

Bodin, Ö., and M. Tengö. 2012. Disentangling intangible socialecological systems. Global Environmental Change 22:430-439. http://dx.doi.org/10.1016/j.gloenvcha.2012.01.005

Burch, S. 2011. Sustainable development paths: investigating the roots of local policy responses to climate change. Sustainable Development 19:176-188. http://dx.doi.org/10.1002/sd.435

Burch, S., A. Shaw, A. Dale, and J. Robinson. 2014. Triggering transformative change: a development path approach to climate change response in communities. Climate Policy 14:467-487. http://dx.doi.org/10.1080/14693062.2014.876342

Conservation of Arctic Flora and Fauna (CAFF). 2013. Arctic biodiversity assessment: status and trends in Arctic biodiversity. CAFF, Akureyri, Iceland.

Cumming, G. S., D. H. M. Cumming, and C. L. Redman. 2006. Scale mismatches in social-ecological systems: causes, consequences, and solutions. Ecology and Society 11(1):14. http:// dx.doi.org/10.5751/ES-01569-110114

Cynara, L. N., P. C. C. Cunha, A. P. Ferreira, and T. C. N. Monteiro. 2006. Hydrodynamics and water quality models applied to Sepetiba Bay. Continental Shelf Research 26:1940-1953. http://dx.doi.org/10.1016/j.csr.2006.06.010

de Castro, F., and D. G. McGrath. 2003. Moving toward sustainability in the local management of floodplain lake fisheries in the Brazilian Amazon. Human Organization 62:123-133. http:// dx.doi.org/10.17730/humo.62.2.9bkh58xeekj6bg0m

Dierking, J., and C. E. Campora. 2009. Ciguatera in the introduced fish Cephalopholis argus (Serranidae) in Hawai'i and implications for fishery management. Pacific Science 63:193-204. http://dx.doi.org/10.2984/049.063.0203

Emery, M., and C. Flora. 2006. Spiraling-up: mapping community transformation with community capitals framework. Community Development 37:19-35. http://dx.doi. org/10.1080/15575330609490152

Fazey, I., J. A. Fazey, J. Fischer, K. Sherren, J. Warren, R. F. Noss, and S. R. Dovers. 2007. Adaptive capacity and learning to learn as leverage for social-ecological resilience. Frontiers in Ecology and the Environment 5:375-380. http://dx.doi.org/10.1890/1540-9295 (2007)5[375:ACALTL]2.0.CO;2

Ford, J. D., L. Berrang-Ford, A. Bunce, C. McKay, M. Irwin, and T. Pearce. 2015. The status of climate change adaptation in Africa and Asia. Regional Environmental Change 15:801-814. http://dx. doi.org/10.1007/s10113-014-0648-2

Ford, J. D., and B. Smit. 2004. A framework for assessing the vulnerability of communities in the Canadian Arctic to risks associated with climate change. Arctic 57:389-400. http://dx.doi. org/10.14430/arctic516

Ford, J. D., A. C. Willox, S. Chatwood, C. Furgal, S. Harper, I. Mauro, and T. Pearce. 2014. Adapting to the effects of climate change on Inuit health. American Journal of Public Health 104: e9-e17. http://dx.doi.org/10.2105/AJPH.2013.301724

Galginaitis, M. 2013. Iñupiat fall whaling and climate change observations from Cross Island. Pages 181-199 in F. J. Mueter, D. M. S. Dickson, H. P. Huntington, J. R. Irvine, E. A. Logerwell, S. A. MacLean, L. T. Quakenbush, and C. Rosa, editors. Responses of Arctic marine ecosystems to climate change. Alaska Sea Grant, University of Alaska Fairbanks, Alaska, USA. http:// dx.doi.org/10.4027/ramecc.2013.09

Garfin, G., and A. Parris. 2016. Climate in context: science and society partnering for adaptation. Wiley \& Sons, London, UK.

Garud, R., and P. Karnøe. 2001. Path dependence and creation. Routledge, London, UK.

Geels, F. W. 2011. The multi-level perspective on sustainability transitions: responses to seven criticisms. Environmental Innovation and Societal Transitions 1(1):24-40. http://dx.doi. org/10.1016/j.eist.2011.02.002

Gentle, P., and T. N. Maraseni. 2012. Climate change, poverty and livelihoods: adaptation practices by rural mountain communities in Nepal. Environmental Science and Policy 21:24-34. http://dx.doi.org/10.1016/j.envsci.2012.03.007

Government of Nepal (GON). 2012. National population and housing census 2011. Central Bureau of Statistics, Government of Nepal, Kathmandu, Nepal.

Halder, P., R. Sharma, and A. Alam. 2012. Local perceptions of and responses to climate change: experiences from the natural resource-dependent communities in India. Regional Environmental Change 12:665-673. http://dx.doi.org/10.1007/s10113-012-0281$\underline{\mathrm{X}}$

Hallwass, G., P. F. Lopes, A. A. Juras, and R. A. M. Silvano. $2013 a$. Fishers' knowledge identifies environmental changes and fish abundance trends in impounded tropical rivers. Ecological Applications 23:392-407. http://dx.doi.org/10.1890/12-0429.1 
Hallwass, G., P. F. M. Lopes, A. A. Juras, and R. A. M. Silvano. 2013b. Behavioral and environmental influences on fishing rewards and the outcomes of alternative management scenarios for large tropical rivers. Journal of Environmental Management 128:274-282. http://dx.doi.org/10.1016/j.jenvman.2013.05.037

Harrison, H. L., and P. A. Loring. 2014. Larger than life: the emergent nature of conflict in Alaska's Upper Cook Inlet salmon fisheries. SAGE Open 4:1-14. http://dx.doi.org/10.1177/2158244014555112

Haynie, A. C., and H. P. Huntington. 2016. Strong connections, loose coupling: the influence of the Bering Sea ecosystem on commercial fisheries and subsistence harvests in Alaska. Ecology and Society 21(4):6. http://dx.doi.org/10.5751/ES-08729-210406

Hovelsrud, G. K., H. Dannevig, J. West, and H. Amundsen. 2010. Adaptation in fisheries and municipalities: three communities in northern Norway. Pages 23-62 in G. K. Hovelsrud and B. Smit, editors. Community adaptation and vulnerability in Arctic regions. Springer, London, UK. http://dx.doi.org/10.1007/978-90-481-9174-1 2

Hovelsrud, G. K., and B. Smit, editors. 2010. Community adaptation and vulnerability in Arctic regions. Springer, London, UK. http://dx.doi.org/10.1007/978-90-481-9174-1

Huntington, H. P. 2011. Arctic science: the local perspective. Nature 478:182-183. http://dx.doi.org/10.1038/478182a

Huntington, H. P., G. Noongwook, N. A. Bond, B. Benter, J. A. Snyder, and J. Zhang. 2013. The influence of wind and ice on spring walrus hunting success on St. Lawrence Island, Alaska. Deep Sea Research Part II: Topical Studies in Oceanography 94:312-322. http://dx.doi.org/10.1016/j.dsr2.2013.03.016

Ifejika Speranza, C., B. Kiteme, P. Ambenje, U. Wiesmann, and S. Makali. 2010. Indigenous knowledge related to climate variability and change: insights from droughts in semi-arid areas of former Makueni District, Kenya. Climatic Change 100:295315. http://dx.doi.org/10.1007/s10584-009-9713-0

Intergovernmental Panel on Climate Change (IPCC). 2014. Climate change 2014: impacts, adaptation, and vulnerability. Intergovernmental Panel on Climate Change, Geneva, Switzerland. [online] URL: http://www.ipcc.ch/report/ar5/wg2/

International Whaling Commission (IWC). 2015. Catch limits for aboriginal subsistence whaling. IWC, Cambridge, UK. [online] URL: https://iwc.int/catches\#aborig

Irvine, K. N., and S. Kaplan. 2001. Coping with change: the small experiment as a strategic approach to environmental sustainability. Environmental Management 28:713-725. http://dx. doi.org/10.1007/s002670010256

Kehew, R. B., M. Kolisa, C. Rollo, A. Callejas, G. Alber, and L. Ricci. 2013. Formulating and implementing climate change laws and policies in the Philippines, Mexico (Chiapas), and South Africa: a local government perspective. Local Environment 18:723-737. http://dx.doi.org/10.1080/13549839.2013.818949

Kelly, P. M., and W. N. Adger. 2000. Theory and practice in assessing vulnerability to climate change and facilitating adaptation. Climatic Change 47:325-352. http://dx.doi. org/10.1023/A:1005627828199
Kersey, B. 2011. Enhancing household food security in times of environmental hazards. Thesis. University of East Anglia, Norwich, UK.

Keskitalo, E. C. H. 2009. Governance in vulnerability assessment: the role of globalising decision-making networks in determining local vulnerability and adaptive capacity. Mitigation and Adaptation Strategies for Global Change 14:185-201. http://dx. doi.org/10.1007/s11027-008-9159-0

Lacerda, L. D., and M. M. Molisane. 2006. Three decades of Cd and $\mathrm{Zn}$ contamination in Sepetiba Bay, SE Brazil: evidence from the mangrove oyster Crassostreaea rhizophorae. Marine Pollution Bulletin 52:974-977. http://dx.doi.org/10.1016/j.marpolbul.2006.04.007

Lebel, L., J. M. Anderies, B. Campbell, C. Folke, S. HatfieldDodds, T. P. Hughes, and J. A. Wilson. 2006. Governance and the capacity to manage resilience in regional social-ecological systems. Ecology and Society 11(1):19. http://dx.doi.org/10.5751/ ES-01606-110119

Lopes, P. F. M., S. Pacheco, M. Clauzet, R. A. M. Silvano, and A. Begossi. 2015. Fisheries, tourism, and marine protected areas: conflicting or synergistic interactions? Ecosystem Services 16:333-340. http://dx.doi.org/10.1016/j.ecoser.2014.12.003

Lopes, P. F. M., R. A. M. Silvano, and A. Begossi. 2011. Extractive and sustainable development reserves in Brazil: resilient alternatives to fisheries? Journal of Environmental Planning and Management 54:421-443. http://dx.doi.org/10.1080/09640568.2010.508687

Loring, P. A. 2013. Are we acquiescing to climate change? Social and environmental justice considerations for a changing Arctic. In F. J. Mueter, D. M. S. Dickson, H. P. Huntington, J. R. Irvine, E. A. Logerwell, S. A. MacLean, L. T. Quakenbush, and C. Rosa, editors. Responses of Arctic marine ecosystems to climate change. Alaska Sea Grant, University of Alaska Fairbanks, Alaska, USA. doi:10.4027/ramecc.2013.01 http://dx.doi.org/10.4027/ramecc.2013.01

Loring, P. A., S. C. Gerlach, D. E. Atkinson, and M. S. Murray. 2011. Ways to help and ways to hinder: governance for effective adaptation to an uncertain climate. Arctic 64:73-88. http://dx.doi. org/10.14430/arctic4081

Loring, P. A., S. C. Gerlach, and H. J. Penn. 2016. "Community work" in a climate of adaptation: responding to change in rural Alaska. Human Ecology 44:119-128. http://dx.doi.org/10.1007/ s10745-015-9800-y

Mack, R. N., D. Simberloff, W. M. Lonsdale, H. Evans, M. Clout, and F. A. Bazzaz. 2000. Biotic invasions: causes, epidemiology, global consequences, and control. Ecological Applications 10:689-710. http://dx.doi.org/10.1890/1051-0761(2000)010[0689: BICEGC]2.0.CO;2

Manandhar, S., V. P. Pandey, and F. Kazama. 2014. Assessing suitability of apple cultivation under climate change in mountainous regions of western Nepal. Regional Environmental Change 14:743-756. http://dx.doi.org/10.1007/s10113-013-0531-6

Manandhar, S., D. S. Vogt, S. R. Perret, and F. Kazama. 2011. Adapting cropping systems to climate change in Nepal: a crossregional study of farmers' perception and practices. Regional Environmental Change 11:335-348. http://dx.doi.org/10.1007/ $\underline{\mathrm{s} 10113-010-0137-1}$ 
McClanahan, T. R., and J. Cinner. 2011. Adapting to a changing environment: confronting the consequences of climate change. Oxford University Press, Oxford, UK. http://dx.doi.org/10.1093/ acprof:oso/9780199754489.001.0001

McGinnis, M. D., and E. Ostrom. 2014. Social-ecological system framework: initial changes and continuing challenges. Ecology and Society 19(2):30. http://dx.doi.org/10.5751/ES-06387-190230

McGrath, D. G., O. T. Almeida, and F. D. Merry. 2007. The influence of community management agreements on house-hold economic strategies: cattle grazing and fishing agreements on the Lower Amazon floodplain. International Journal of the Commons 1:67-87. http://dx.doi.org/10.18352/ijc.54

McGrath, D. G., A. Cardoso, O. T. Almeida, and J. Pezzuti. 2008. Constructing a policy and institutional framework for an ecosystem-based approach to managing the Lower Amazon floodplain. Environment, Development and Sustainability 10:677-695. http://dx.doi.org/10.1007/s10668-008-9154-3

McGrath, D. G., F. de Castro, C. Futemma, B. D. de Amaral, and J. Calabria. 1993. Fisheries and the evolution of resource management on the lower Amazonian floodplain. Human Ecology 21:167-195. http://dx.doi.org/10.1007/BF00889358

McGray, H., R. Bradley, A. Hammill, E. L. Schipper, and J.-E. Parry. 2007. Weathering the storm: options for framing adaptation and development. World Resources Institute, Washington, D.C., USA.

Monnereau, I., and S. Abraham. 2013. Limits to autonomous adaptation in response to coastal erosion in Kosrae, Micronesia. International Journal of Global Warming 5(4):416-432. http://dx. doi.org/10.1504/IJGW.2013.057283

Mustonen, T. 2012. Rebirth of indigenous Arctic nations and polar resource management: critical perspectives from Siberia and Sámi areas of Finland. Biodiversity 14:18-27.

Mustonen, T. 2013. Oral histories as a baseline of landscape restoration - co-management and watershed knowledge in Jukajoki River. Fennia 191:76-91. http://dx.doi.org/10.11143/7637

Mustonen, T. 2014a. Endemic time-spaces of Finland: aquatic regimes. Fennia 192(2):120-139. http://dx.doi.org/10.11143/40845

Mustonen, T. 2014b. Power discourses of fish death: case of Linnunsuo peat production. Ambio 43:234-243. http://dx.doi. org/10.1007/s13280-013-0425-3

Mustonen, T., and P. Feodoroff. 2013. Ponoi and Neiden collaborative management plan. Snowchange Cooperative, Kontiolahti, Finland.

Mustonen, T., and K. Mustonen. 2011. Eastern Sámi Atlas. Snowchange Cooperative, Kontiolahti, Finland.

Nakashima, D. J., K. Galloway McLean, H. D. Thulstrup, A. Ramos Castillo, and J. T. Rubis. 2012. Weathering uncertainty: traditional knowledge of climate change assessment and adaptation. UNESCO, Paris, France, and United Nations University, Darwin, Australia.

Nasiko, R. 2013. Fishing council to issue licenses. The Fiji Times, 18 December.
Nilsson, A. E., Å. Gerger Swartling, and K. Eckerberg. 2012. Knowledge for local climate change adaptation in Sweden: challenges of multilevel governance. Local Environment 17:751-767. http://dx.doi.org/10.1080/13549839.2012.678316

Noongwook, G., the Native Village of Savoonga, the Native Village of Gambell, H. P. Huntington, and J. C. George. 2007. Traditional knowledge of the bowhead whale (Balaena mysticetus) around St. Lawrence Island, Alaska. Arctic 60:47-54.

Oliver-Smith, A. 2013. Disaster risk reduction and climate change adaptation: the view from applied anthropology. Human Organization 72:275-282. http://dx.doi.org/10.17730/humo.72.4. j7u 8054266386822

Ostrom, E. 2005. Understanding institutional diversity. Princeton University Press, Princeton, New Jersey, USA.

Ostrom, E. 2007. Institutional rational choice: an assessment of the institutional analysis and development framework. Pages 21-64 in P. A. Sabatier, editor. Theories of the policy process. Second edition. Westview Press, Cambridge, Massachusetts, USA.

Ostrom, E. 2009. A general framework for examining sustainability of social-ecological systems. Science 325:419-422. http://dx.doi.org/10.1126/science.1172133

Ostrom, E. 2010. Polycentric systems for coping with collective action and global environmental change. Global Environmental Change 20(4):550-557. http://dx.doi.org/10.1016/j.gloenvcha.2010.07.004

Patton, M. Q. 2015. Qualitative research and evaluation methods: integrating theory and practice. Fourth edition. Sage, Thousand Oaks, California, USA.

Perry, R. I., R. E. Ommer, M. Barange, S. Jentoft, B. Neis, and U. R. Sumaila. 2011. Marine social-ecological responses to environmental change and the impacts of globalization. Fish and Fisheries 12:427-450. http://dx.doi.org/10.1111/j.1467-2979.2010.00402. $\underline{\mathrm{X}}$

Petrere Jr., M. 1996. Fisheries in large tropical reservoirs in South America. Lakes and Reservoirs: Research and Management 2:111-133. http://dx.doi.org/10.1111/j.1440-1770.1996.tb00054. $\underline{x}$

Ribeiro, M. C. L. B., M. Petrere Jr., and A. A. Juras. 1995. Ecological integrity and fisheries ecology of the AraguaiaTocantins River Basin, Brazil. Regulated Rivers: Research and Management 11:325-350. http://dx.doi.org/10.1002/rrr.3450110308

Shackleton, S., G. Ziervogel, S. Sallu, T. Gill, and P. Tschakert. 2015. Why is socially-just climate change adaptation in subSaharan Africa so challenging? A review of barriers identified from empirical cases. Wiley Interdisciplinary Reviews: Climate Change 6:321-344. http://dx.doi.org/10.1002/wcc.335

Shine, R., and J. S. Doody. 2011. Invasive species control: understanding conflicts between researchers and the general community. Frontiers of Ecology and the Environment 9:400-406. http://dx.doi.org/10.1890/100090

Silvano, R. A. M., and A. Begossi. 1998. The artisanal fishery of Piracicaba River (São Paulo, Brazil): fish landing composition and environmental alterations. Italian Journal of Zoology 65:527-531. http://dx.doi.org/10.1080/11250009809386879 
Silvano, R. A. M., and A. Begossi. 2001. Seasonal dynamics of fishery at the Piracicaba River (Brazil). Fisheries Research 51:69-86. http://dx.doi.org/10.1016/S0165-7836(00)00229-0

Silvano, R. A. M., and A. Begossi. 2002. Ethnoichthyology and fish conservation in the Piracicaba River (Brazil). Journal of Ethnobiology 22:285-306.

Silvano R. A. M., G. Hallwass, A. A. Juras, and P. F. M. Lopes. 2017. Assessment of efficiency and impacts of gillnets on fish conservation in a tropical freshwater fishery. Aquatic Conservation: Marine and Freshwater Ecosystems 27:521-533. http://dx.doi.org/10.1002/aqc.2687

Silvano, R. A. M., G. Hallwass, P. F. Lopes, A. R. Ribeiro, R. P. Lima, H. Hasenack, A. A. Juras, and A. Begossi. 2014. Comanagement and spatial features contribute to secure fish abundance and fishing yields in tropical floodplain lakes. Ecosystems 17:271-285. http://dx.doi.org/10.1007/s10021-013-9722-8

Silvano, R. A. M., A. A. Juras, and A. Begossi. 2009. Clean energy and poor people: ecological impacts of hydroelectric dam on fish and fishermen in the Amazon rainforest. Pages 139-147 in $V$ International Conference on Energy, Environment, Ecosystems and Sustainable Development and II International Conference on Landscape Architecture. WSEAS Press, Greece.

Smit, B., and J. Wandel. 2006. Adaptation, adaptive capacity and vulnerability. Global Environmental Change 16:282-292. http://dx. doi.org/10.1016/j.gloenvcha.2006.03.008

Thornton, T. F., and N. Manasfi. 2010. Adaptation-genuine and spurious: demystifying adaptation processes in relation to climate change. Environment and Society: Advances in Research 1:132-155. http://dx.doi.org/10.3167/ares.2010.010107

Tompkins, E. L., and W. N. Adger. 2005. Defining response capacity to enhance climate change policy. Environmental Science and Policy 8:562-571. http://dx.doi.org/10.1016/j.envsci.2005.06.012

Trimble, M., and D. Johnson. 2013. Artisanal fishing as an undesirable way of life? The implications for governance of fishers' wellbeing aspirations in coastal Uruguay and southeastern Brazil Marine Policy 37:37-44. http://dx.doi. org/10.1016/j.marpol.2012.04.002

Tschakert, P., and K. A. Dietrich. 2010. Anticipatory learning for climate change adaptation and resilience. Ecology and Society 15 (2):11. http://dx.doi.org/10.5751/ES-03335-150211

Uhlig, H. 1978. Geoecological controls of high-altitude rice cultivation in the Himalayas and mountain regions of Southeast Asia. Arctic and Alpine Research 10:519-529. http://dx.doi. org/10.2307/1550785

United Nations Development Programme (UNDP). 2012. Fiji locally-managed marine area network, Fiji. Equator Initiative Case Study Series. UNDP, New York, New York, USA.

United Nations Development Programme(UNDP). 2014. UNEP Yearbook 2014. United Nations Environment Programme, Nairobi, Kenya.

Walker, B., and D. Salt. 2012. Resilience practice: building capacity to absorb disturbance and maintain function. Island Press, Washington, D.C., USA. http://dx.doi.org/10.5822/978-1-61091-231-0
Waring, T. M., M. A. Kline, J. S. Brooks, S. H. Goff, J. Gowdy, M. A. Janssen, P. E. Smaldino, and J. Jacquet. 2015. A multilevel evolutionary framework for sustainability analysis. Ecology and Society 20(2):34. http://dx.doi.org/10.5751/ES-07634-200234

Welcomme, R. L., I. G. Cowx, D. Coates, C. Béné, S. Funge-Smith, A. Halls, and K. Lorenzen. 2010. Inland capture fisheries. Philosophical Transactions of the Royal Society B 365:2881-2896. http://dx.doi.org/10.1098/rstb.2010.0168

Winterhalder, B. 1980. Environmental analysis in human evolution and adaptation research. Human Ecology 8:135-170. http://dx.doi.org/10.1007/BF01531439

Yates, D. 2000. Where's the salmon? Fish abandon Yukon and Kuskowim Rivers. The Council: a report to the member tribes for the Tanana Chiefs Conference. Tanana Chiefs Conference, Fairbanks, Alaska, USA.

Yin, R. K. 2009. Case study research: design and methods. Fourth edition. SAGE, Thousand Oaks, California, USA. 